\title{
Stature, Sitting Height and Relative Sitting Height of Female Northern Kyushuites
}

\author{
Teruyuki HOJO', Tamiji NAKASHima' and Tomi HiRAO ${ }^{2}$ \\ 'Department of Anatomy and Anthropology, School of Medicine, University of Occupational and \\ Environmental Health, Japan. Kitakyushu 807, Japan \\ 'Student of School of Medicine, University of Occupational and Environmental Health, Japan. \\ Kitakyushu 807, Japan
}

\begin{abstract}
Stature, sitting height and relative sitting height (a ratio of sitting height to stature) of 318 high school girls of 17 years of age in Kitakyushu City were studied. They consisted of groups over a three-year period; 1973, 1980 and 1984. There are statistically no significant changes in the stature, in the sitting height, and in the relative sitting height among these three groups. The relative sitting height of these three groups is about $54 \%$, which is about the same as among the Chinese, Eskimos, American-Indians and the Hokkaido-Ainu.
\end{abstract}

Key words: stature, relative sitting height, female Northern Kyushuites.

(Received 15 August 1984)

\section{Introduction}

Hojo et al. (1981) described that the secular unchangeability in relative sitting height (a ratio of sitting height to stature) of female Northern Kyushuites. This study was made as one of the studies of growth, of Northern Kyushuites from the anthropological viewpoint. Regarding the physical growth we must consider environmental and genetic differences. From this point of view the subjects of this study were limited to ones born and living in the Northern Kyushu district. They are the pupils of the same high school as those of the former study, Orio Women's High School.

\section{Materials and Methods}

As shown in Table 1, materials used in this study were 318 female Northern Kyushuites and consist of groups over a three-year period; 1973, 1980 and 1984. These data are those of 17-year-old high school girls of Orio Women's High School, located in Northern Kyushu, Kitakyushu City. Stature and sitting height are measured according to the anthropometry of the Martin-Saller's method (Martin \& Saller, 1957). 
Table 1. Numbers, means and standard deviations of stature, sitting height and relative sitting height of 17 -year-old female Northern Kyushuites

\begin{tabular}{|c|c|c|c|c|c|c|c|c|c|}
\hline \multirow[b]{2}{*}{ Item } & \multicolumn{3}{|c|}{1973} & \multicolumn{3}{|c|}{1980} & \multicolumn{3}{|c|}{1984} \\
\hline & $\mathrm{N}$ & Mean & $\mathrm{SD}$ & $\mathrm{N}$ & Mean & $\mathrm{SD}$ & $\mathrm{N}$ & Mean & $\mathrm{SD}$ \\
\hline Stature $(\mathrm{cm})$ & 256 & 155.59 & 4.92 & 41 & 156.38 & 4.65 & 21 & 154.33 & 4.73 \\
\hline $\begin{array}{r}\text { Sitting height } \\
(\mathrm{cm})\end{array}$ & 256 & 84.61 & 2.63 & 41 & 85.00 & 3.22 & 21 & 83.39 & 2.50 \\
\hline $\begin{array}{l}\text { Relative sitting } \\
\text { height }(\%)\end{array}$ & 256 & 54.4 & 1.35 & 41 & 54.4 & 1.33 & 21 & 54.0 & 0.90 \\
\hline
\end{tabular}

\section{Results and Discussion}

As shown in the Table 1, the relative sitting heights of groups over a three-year period are nearly equal, from $54.0 \%$ to $54.4 \%$, and the mean stature in 1984 is statistically insignificantly smaller than that in 1980 (by t-test; $\mathrm{t}<1.62$ ).

On the other hand, it is said that relative sitting heights show certain differences among different ethnic groups, for example, in Australian Aborigines and in many Black peoples from $45 \%$ to $50 \%$; in the Chinese, Eskimos and American Indians from $53 \%$ to 54\% (Harrison et al., 1964); in the Hokkaido-Ainu 54.6\% (Martin \& Saller, 1959).

By combining the results of our former study (Hojo et al., 1981) with this present paper, it is evident that among these groups over a three-year period there are no statistically significant changes either in the stature, or in the relative sitting height. The mean values of their relative sitting heights, about $54 \%$, are common to those of the Chinese, Eskimos, American Indians and the Hokkaido-Ainu.

\section{Acknowledgements}

We wish to express our appreciation to the staff and the pupils of the Orio Women's High School for their kind permission to make this anthropometrical study.

\section{References}

Harrison, G. A., Weiner, J. S., Tanner, J. M. et al. (1964): Human Biology. An introduction to human evolution, variation and growth. Oxford at the Clarendon Press. pp. 206-207.

Hojo, T., Takemoto, R. \& Shinoda, K. (1981): The secular unchangeability in relative sitting height of female Kyushuites. J. UOEH, 3: 203-205.

Martin, R. \& Saller, K. (1957): Lehrbuch der Anthropologie. Bd. I. Gustav Fischer Verlag, Stuttgart. pp. $273-429$.

Martin, R. \& Saller, K. (1959): Lehrbuch der Anthropologie. Bd. II. Gustav Fischer Verlag, Stuttgart. pp. 883-884. 
北九州人女子の身長，座高および比座高

北條 鼍幸 ${ }^{1}$ 中島 民治 ${ }^{1} \cdot$ 平尾 登美 2

1産業医科大学第一解剖学教室 2産業医科大学医学部学生

要 旨：北九州市在住の 17 オの女子高生，318名の身長，座高および比座高（身長に対する座高 の百分率）を対象に研究した。計測は，Martin-Saller 法に基ういて行わ机た。計測值 は1973 年，1980 年および 1984 年に計測された 3 群に分けられ，これら了群間に身長，

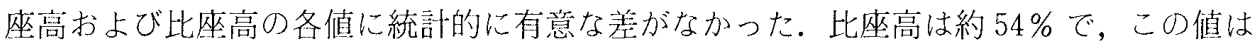
3群に共通であるばかりでなく，若干の中国人，エスキモー人，アメリカ・インディアン および北海道アイヌ人に共通である。

J. UOEH（産業医大誌)，6 (4):355-357 (1984) 